\title{
Review Article: Immobilized Molecules Using Biomaterials and Nanobiotechnology
}

\section{Magdy M. M. Elnashar}

Centre of Scientific Excellence, Polymers Department, Advanced Materials \& Nanotechnology Laboratory, National Research Center, Cairo, Egypt.

Email: magmel@gmail.com

Received August 24 $4^{\text {th }}, 2010$; revised October 15 $5^{\text {th }}, 2010$; accepted October $21^{\text {st }}, 2010$.

\begin{abstract}
Immobilized molecules using biomaterials and nanobiotechnology is a very interesting topic that touching almost all aspects of our life. It uses the sciences of biology, chemistry, physics, materials engineering and computer science to develop instruments and products that are at the cutting edge of some of today's most promising scientific frontiers. In this review article, the author based on his experience in this arena has tried to focus on some of the supports for immobilization; the most important molecules to be immobilized such as DNA, cells, enzymes, metals, polysaccharides, etc and their applications in medicine, food, drug, water treatment, energy and even in aerospace. He specified a special section on what is new in the arena of supports and technologies used in enzyme immobilization and finally a recommendation by the author for future work with a special attention to up-to-date references.
\end{abstract}

Keywords: Immobilized molecules, Biotechnology, Enzymes, Biomaterials, Nanobiotechnology

\section{Introduction}

\subsection{Some Important Definitions}

\subsubsection{Definition of Biotechnology}

The European Federation of Biotechnology defined biotechnology as "the integration of natural sciences and engineering in order to achieve the application of organisms, cells, parts thereof and molecular analogues for products and services" [1]. In other words, Biotech applications can be divided into 5 key sectors: biomedicine, bioagriculture, industrial biotechnology, bioenergy, and bioenvironment.

\subsubsection{Definition of Immobilization}

An immobilized molecule is one whose movement in space has been restricted either completely or to a small limited region by attachment to a solid structure. In general the term immobilization refers to the act of the limiting movement or making incapable of movement i.e., retard the movement [2].

\subsection{History of Immobilization}

Immobilization is a natural phenomenon existing in the universe. Microorganisms in nature are irregularly distributed and often exist in Biofilms. Biofilms are surface-attached microbial communities consisting of mul- tiple layers of cells embedded in hydrated matrices [3]. Biofilms were first extensively studied during the $1940 \mathrm{~s}$ but it was not until the 1970s that it was appreciated that their formation occurs in almost all natural environments. A rock immersed in a stream, an implant in the human body, a tooth, a water pipe or conduit, etc. are all sites where Biofilms develop [4]. This natural phenomenon encouraged humans to utilize it for his services.

\subsection{What Can We Immobilize?}

Many molecules have been immobilized and the majority of them are biomolecules due to their biological and biomedical applications. The following are examples of some of these molecules:

- Proteins:

- Enzymes, antibodies, antigens, cell adhesion molecules and "Blocking" proteins

- Peptides:

- Substances composed of amino acids

- Drugs:

- Anticancer agents, antithrombogenic agents, antibiotics, contraceptives, drug antagonists and peptide/protein drugs

- Saccharides:

- Sugars, oligosaccharides and polysaccharides 
- Lipids:

- Fatty acids, phospholipids, glycolipids and any fatlike substances.

- Ligands:

- Hormone receptors, cell surface receptors, avidin and biotin

- In immunology, small molecules that are bound to another chemical group or molecule

- Nucleic acids and nucleotides:

- DNA, RNA

- High MW substances formed of sugars, phosphoric acid, and nitrogen bases (purines and pyrimidines).

- Others:

- Conjugates or mixtures of any of the above

\subsection{Methods of Immobilization}

The methods of immobilization of the different molecules are almost the same. However, according to Cao, L. 2005 [5] there is no general universally applicable method of certain molecule immobilization. As enzyme molecules alone or in combination with drugs, antibodies and antigens, are the most used in industries, we will be focusing on the immobilization techniques used for enzymes as a model of other immobilized molecules. The enzyme market in 2005 was around 2.65 billion dollars, with an expected annual growth of more than $9 \%$ [6]. On the industrial level, $75 \%$ of the enzymes were used, which is around 2 billion dollars.

However, expensive enzymes are not favored to be used in industries in the Free State as they are difficult to be separated from the products (Figure 1(a)) and conse- quently are lost after the first use. They were alternatively immobilized on solid supports (Figure 1(b)) so that they can be easily separated from the products by simple filtration or using a fluidized magnetized bed reactor system [7-14].

The main advantage for enzyme immobilization is the easy separation of the enzyme from the reaction mixture (substrates and products) and its reusability for tens of time, which reduces the enzyme and the enzymatic products cost tremendously. Beside this splendid advantage, the immobilization process imparts many other advantages to the enzyme such as:

- The ability to stop the reaction rapidly by removing the enzyme from the reaction solution (or vice versa)

- Product is not contaminated with the enzyme

- Easy separation of enzyme from the product (especially useful in food and pharmaceutical industries)

- Enhancement of enzyme stability against $\mathrm{pH}$, temperature, solvents, contaminants, and impurities.

Immobilization provides a physical support for enzymes, cells and other molecules. Immobilization of enzymes is one of the main methods used to stabilize free enzymes $[7,8]$. The support material and the main methods of immobilization are key parameters in enzyme immobilization. There are five principal methods for immobilization of enzymes and cells (adsorption, covalent, entrapment, encapsulation and crosslinking) and no one method is perfect for all molecules or purposes. However, Katzbauer and Moser, 1995 [15] represented a classification of combination between these methods.

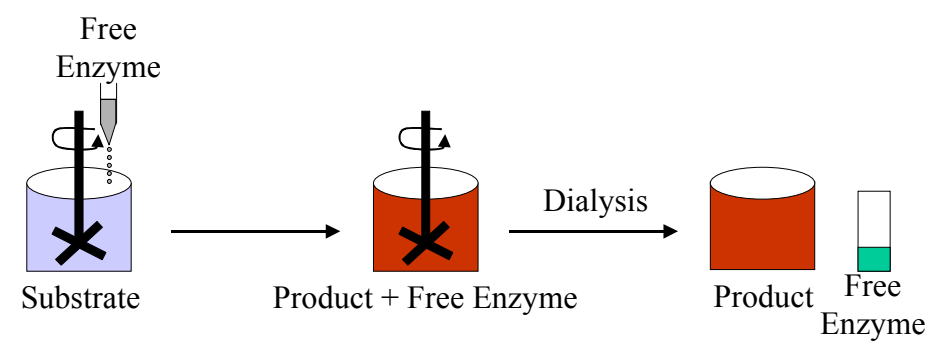

(a)

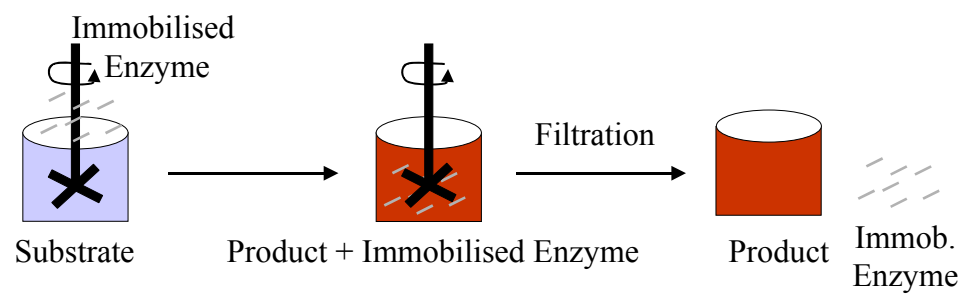

(b)

Figure 1. Schematic diagram of free and immobilized enzyme reactions. (a) Reaction of free enzyme with substrate and formation of product, which has to be separated via dialysis; (b) Reaction of immobilized enzyme with substrate and formation of product, which can be separated via filtration or using a fluidized magnetized bed reactor system. 


\subsubsection{Adsorption}

Immobilization by adsorption is the simplest method and involves reversible surface interactions between enzyme and support material as shown in Figure 2. The procedure of adsorption consists of mixing together the biological component(s) and a support with adsorption properties, under suitable conditions of $\mathrm{pH}$ and ionic strength for a period of incubation, followed by collection of the immobilized material and extensive washing to remove the unbound biological components. The first industrially used immobilized enzyme was prepared by adsorption of amino acid acylase on DEAE-cellulose [16]. Menaa et al. (2008a) [17] reported the role of hydrophobic surfaces of nanoporous silica glasses on protein folding enhancement.

Advantages of enzymes immobilized using the adsorption technique:

- Reversibility, which enables not only the purification of proteins but also the reuse of the carriers;

- Simplicity, which enables enzyme immobilization under mild conditions;

- Possible high retention of activity because there is no chemical modification [18];

- Cheap and quick method;

- No chemical changes to the support or enzyme occurs.

Disadvantages of enzymes immobilized using the adsorption technique:

- The immobilized enzymes prepared by adsorption tend to leak from the carriers, owing to the relatively weak interaction between the enzyme and the carrier, which can be destroyed by desorption forces such as high ionic strength, $\mathrm{pH}$, etc,

- Contamination of product,

- Non-specific binding,

- Overloading on the support and

- Steric hindrance by the support.

Consequently, a number of variations have been developed in recent decades to solve this intrinsic drawback. Examples are adsorption-cross-linking; modificationadsorption; selective adsorption-covalent attachment; and adsorption-coating, etc. For more details, the reader is recommended to read the book of Cao L, 2005 [5].

\subsubsection{Covalent Binding}

This method of immobilization involves formation of a covalent bond between the enzyme and support material as shown in Figure 3. Covalent bonds usually provide the strongest linkages between enzyme and carrier, compared with other types of enzyme immobilization methods. Thus, leakage of enzyme from the matrix used is often minimized with covalently bound immobilized enzymes [5]. The bond is normally formed between functional groups present on the surface of the support and functional groups belonging to amino acid residues on the surface of the enzyme.

Multi-step immobilization is one of the technologies to enhance enzyme covalent immobilization [19]. There are many reaction procedures for coupling an enzyme to a support via covalent bond however, most reactions fall into the following categories: formation of an isourea linkage; formation of a diazo linkage; formation of a peptide bond or an alkylation reaction as shown in Table 1.

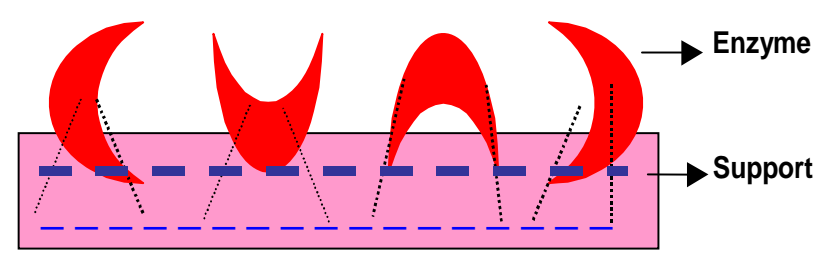

Figure 2. Immobilization of enzymes using the adsorption technique.

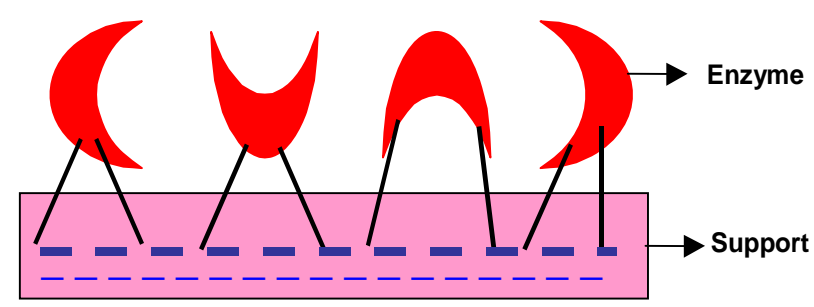

Figure 3. Immobilization of enzymes using the covalent technique.

Table 1. Different methods for covalent binding of enzymes to supports.

\begin{tabular}{ll}
\hline \multicolumn{1}{c}{ Reaction } & \multicolumn{1}{c}{ Support - Enzyme Linkage } \\
\hline Diazotization & SUPPORT--N=N---ENZYME \\
Alkylation and arylation & SUPPORT--CH2-NH---ENZYME \\
Schiff's base formation & SUPPORT--CH2-S---ENZYME \\
Amide bond formation & SUPPORT---CH=N---ENZYME \\
Amidation reaction & SUPPORT---CO-NH---ENZYME \\
Thiol-Disulfide interchange & SUPPORT---CNH-NH---ENZYME \\
Carrier binding with bifunctional reagents & SUPPORT---S-S---ENZYME \\
\hline
\end{tabular}


Advantages of enzymes immobilized using the covalent technique:

- No leakage of enzyme.

- The enzyme can be easily in contact to substrate due to the localization of enzyme on support materials.

- Increase of the thermal stability.

Disadvantages of enzymes immobilized using the covalent technique:

- The cost is quite high as the good supports are very expensive (e.g. Eupergit $\mathrm{C}$ and Agaroses).

- Loss of enzyme activity (e.g. mismatched orientation of enzyme on the carriers such as involvement of active centre in the binding).

\subsubsection{Entrapment}

Immobilization by entrapment differs from adsorption and covalent binding as shown in Figure 4 in that enzyme molecules are free in solution, but restricted in movement by the lattice structure of a gel [20]. The porosity of the gel lattice is controlled to ensure that the structure is tight enough to prevent leakage of enzyme or cells, yet at the same time allows free movement of substrate and product. The support also acts as a barrier and can be advantageous as it protects the immobilized enzyme from microbial contamination by harmful cells, proteins, and enzymes in the microenvironment [21].

Entrapment can be achieved by mixing an enzyme with a polyionic polymer material, such as carrageenan, and by crosslinking the polymer with multivalent cations, e.g. hexamethylene diamine, in an ion-exchange reaction to form a lattice structure that traps the enzymes, this is termed ionotropic gelations.

Advantages of enzymes immobilized using the entrapment technique:

- Enzyme loading is very high

Disdvantages of enzymes immobilized using the entrapment technique:

- Enzyme leakage from the support.

- Diffusion of the substrate to the enzyme and of the product away from the enzyme (diffusion limitation).

\subsubsection{Encapsulation}

Encapsulation of enzymes as shown in Figure 5 can be achieved by enveloping the biological components within various forms of semipermeable membranes [22]. It is similar to entrapment in that the enzyme is free in solution, but restricted in space. Large proteins or enzymes can not pass out of, or into the capsule, but small substrates and products can pass freely across the semipermeable membrane. Many materials have been used to construct microcapsules varying from 10-100 $\mu \mathrm{m}$ in diameter. For example, nylon and cellulose nitrate have proven popular. Ionotropic gelation of alginates have proven it efficacy as well for encapsulation of drugs, enzymes and cells [23]. On the nano scale level, Menaa et al., 2008b, 2009 \& 2010 [24-26] used Silicabased nanoporous sol-gel glasses for the study of encapsulation and stabilization of some proteins.

Advantages of enzymes immobilized using the encapsulation technique:

- The enzymes could be encapsulated inside the cell.

- Possibility of coimmobilization. Where cells and/or enzymes may be immobilized in any desired combination to suit particular applications.

Disdvantages of enzymes immobilized using the entrapment technique:

- The problems associated with diffusion are acute and may result in rupture of the membrane if products from a reaction accumulate rapidly.

\subsubsection{Crosslinking}

This type of immobilization is support-free as shown in Figure 6 and involves joining enzyme molecules to each other to form a large, three-dimensional complex structure, and can be achieved by chemical or physical methods [19]. Chemical methods of crosslinking normally

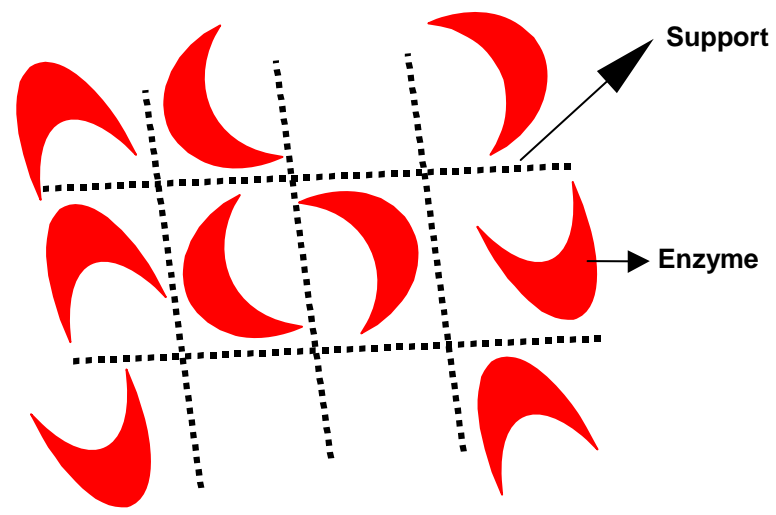

Figure 4. Immobilization of enzyme using the entrapment technique.

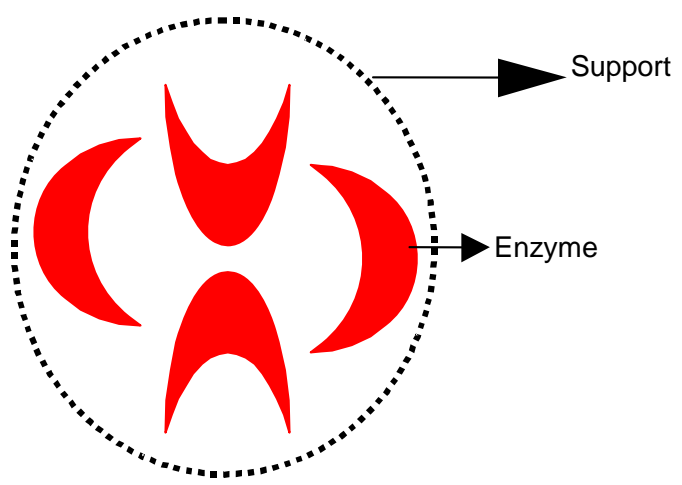

Figure 5. Immobilization of enzymes using the encapsulation technique. 


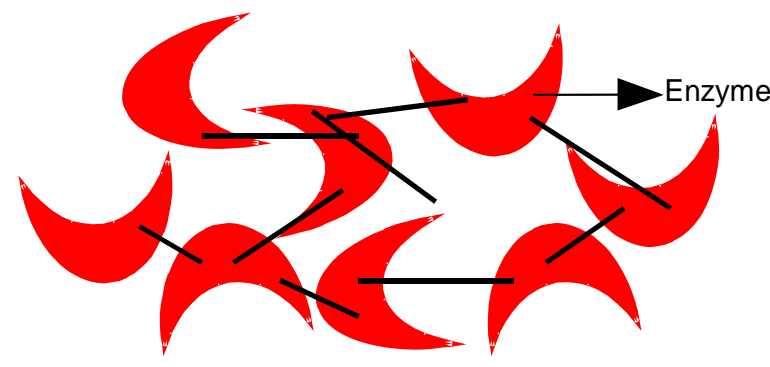

Figure 6. Crosslinking technique.

involve covalent bond formation between the enzymes by means of a bi- or multifunctional reagent, such as glutaraldehyde, dicarboxylic acid or toluene diisocyanate. Flocculating agents, such as polyamines, polyethyleneimine, polystyrene sulfonates, and various phosphates, have been used extensively to cross-link cells using physical bonds. Crosslinking is rarely used as the only means of immobilization, because poor mechanical properties of the aggregates are severe limitations. Crosslinking is most often used to enhance the other methods of immobilization described.

Advantages of enzymes immobilized using the crosslinking technique:
- The immobilization is support-free.

- Cross-linking between the same enzyme molecules stabilises the enzymes by increasing the rigidity of the structure

Disdvantages of enzymes immobilized using the crosslinking technique:

- Harshness of reagents of crooslinking is a limiting factor in applying this method to many enzymes.

- The enzyme may partially lose activity or become totally inactivated in case the cross-linking reagent reacted across the active site.

\subsection{Examples of Matrices and Shapes for Immobilization}

Matrices for immobilization can be classified according to their chemical composition as organic and inorganic supports. The former can be further classified into natural and synthetic matrices as in Table 2 [27].

The shape of the carrier can be classified into two types, i.e. irregular and regular shapes such as (A): beads; (B): fibres; (C): hollow spheres; (D): thin films; (E): discs and (F): membranes. Selection of the geometric properties for an immobilized molecule is largely dependent on the peculiarity of certain applications.

Table 2. Chemical classification of enzyme matrices.

\begin{tabular}{|c|c|}
\hline Organic & Inorganic \\
\hline Natural polymers & $\underline{\text { Minerals }}$ \\
\hline Polysaccharides & Attapulgite clays \\
\hline Cellulose & Bentonite \\
\hline Dextran & Kieselgur \\
\hline Starch & Pumic stone \\
\hline Agar and agarose & Hornblend \\
\hline Alginate & Diatomaceous earth \\
\hline Carrageenans & Sand \\
\hline \multicolumn{2}{|l|}{ Chitin and chitosan } \\
\hline \multicolumn{2}{|l|}{ Proteins } \\
\hline \multicolumn{2}{|l|}{ Collagen } \\
\hline \multicolumn{2}{|l|}{ Gelatin } \\
\hline \multicolumn{2}{|l|}{ Albumin } \\
\hline \multicolumn{2}{|l|}{ Ferritin } \\
\hline Synthetic polymers & $\underline{\text { Fabricated materials }}$ \\
\hline Polystyrene & Non-porous glass \\
\hline Polyacrylate and polymethacrylate & Controlled pore glass \\
\hline Polyacrylamides & Controlled pore metal oxides \\
\hline Hydroxyalkyl methacrylate & Alumina catalyst \\
\hline Vinyl polymer & Porous silica \\
\hline Maleic anhydride polymer & Silochrome \\
\hline Polyethyleneglycol & Iron oxide \\
\hline Aldehyde-based polymer & Stainless steel \\
\hline
\end{tabular}


Gel disks are widely used in the literature. Researchers usually use the casting method, e.g. a Petri dish, to make a single film of gel and then cut it into disks using cork borers. Elnashar et al., 2005 [28], invented a new equipment to make many uniform films in one step and with high accuracy using the equipment "Parallel Plates" as shown in Figure 7.

Gel beads are mostly used in industries as they have the largest surface area and can be formed by many techniques such as the interphase technique, ionic gelation methods, dripping method and the Innotech Encapsulator $[7,10]$. The Innotech Encapsulator as shown in Figure 8 has the advantage of high bead production $(50-3000$ beads per second depending on bead size and encapsulation-product mixture viscosity), which is suitable for the scaling up production on the industrial scale.

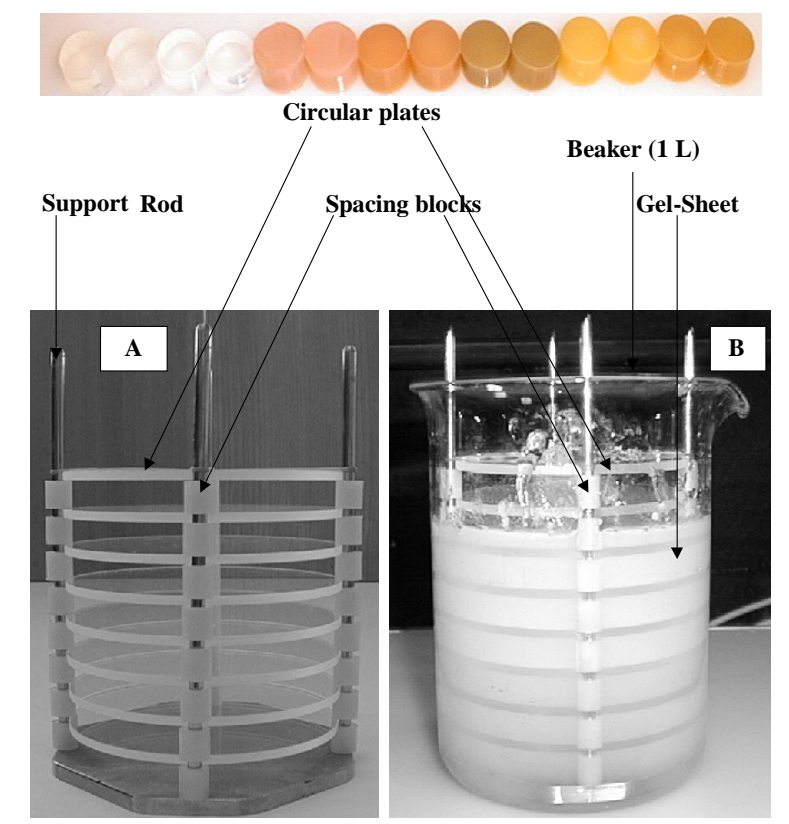

Figure 7. Parallel plates equipment for making uniform k-carrageenan gel disks.

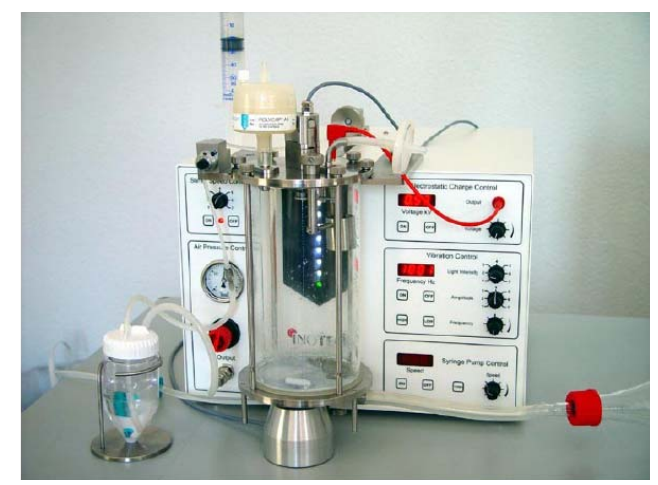

Figure 8. Inotech Encapsulator IE-50 R.

\subsection{Properties of Matrices for Immobilization}

The supports on which molecules such as enzymes, antibodies, antigens, etc will be immobilized are of great interest. The term support or media is usually understood to refer to a combination of a ligand that is firmly attached often by covalent means, and a solid insoluble matrix. These supports have to exhibit good chemical and physical stability and contain available functional groups to bind to the active molecule. To use a support for immobilization of active molecules such as enzymes, a range of fundamental properties are required, which are summarised as follows [20].

a) Availability of matrix from a reliable commercial source

b) Matrix has an abundance of easily derivatizable functional groups

c) Matrix has good mechanical and chemical stability

d) Matrix has good capacity for the target molecule

e) Matrix material is "user friendly"

\section{Applications of Immobilized Molecules}

\subsection{Drug Delivery Systems}

Advanced drug delivery systems (ADDS) have found applications in many biomedical fields [29,30]. Drug delivery is a combination of material science, pharmaceutics and biology [31]. Adoption of different types of membranes in ADDS has made it possible to release drug in an optimal fashion according to the nature of a disease [32]. Examples of drug delivery systems include glucose-sensitive insulin and drug loaded magnetic nanoparticles.

\subsubsection{Development of Glucose-Sensitive Insulin}

The swelling or shrinking of smart hydrogel beads in response to small changes in $\mathrm{pH}$ or temperature can be used successfully to control drug release, because the diffusion of the drug out of the beads depends on the gel state [33].

Drug-delivery systems in which a drug is liberated in response to a chemical signal (e.g. insulin release in response to rising glucose concentration) can be achieved using this system. The exposure of a glucosesensitive insulin releasing system to glucose resulted in the oxidation of glucose to gluconic acid and thus a decrease in the $\mathrm{pH}$, protonation and shrinking of the polymer, leading to an increased release of insulin. The polymer swells in size at normal body $\mathrm{pH}(\mathrm{pH}=7.4)$ and closes the gates. It shrinks at low $\mathrm{pH}(\mathrm{pH}=4)$ when the blood glucose level increases, thus opening the gates and releasing the insulin from the nanoparticles [34].

\subsubsection{Drug Loaded Magnetic Nanoparticles}

Nanotechnology offers the means to send the drugs to 
targeted sites, and has the drug released in a controlled manner, which reduce side effects due to lower dosage and minimize or prevent drug degradation by using pathways other than gastrointestinal. Magnetic nanoparticles are recently applied in various fields such as MRI imaging, water treatment, hyperthermia and drug delivery systems. Drug loaded magnetic nanoparticles (DLMNP) have several advantages such as: small particle size; large surface area; magnetic response; biocompatibility and non-toxicity. DLMNP is introduced through injection and directed with external magnets to the right organ, which requires smaller dosage because of targeting, resulting in fewer side effects.

Recently, Yu et al., 2008 [35] reported a novel In Vivo strategy for combined cancer imaging and therapy by employing thermally cross-linked superparamagnetic iron oxide nanoparticles as a drug-delivery carrier. Whereas, Kettering et al., 2009 [36] used magnetic iron nanoparticles with cisplatin adsorbed in them for drug release in magnetic heating treatments for cancer.

\subsection{Enzyme-Linked Immunosorbent Assays (ELISA)}

ELISA is a test used as a general screening tool for the detection of antibodies or antigens in a sample [37]. ELISA technology links a measurable enzyme to either an antigen or antibody. The procedure for detection of $\mathrm{Ab}$ in patient's sample as follows:

- Immobilize Ag on the solid support (well)

- Incubate with patient sample

- Add antibody-enzyme conjugate

- Amount of antibody-enzyme conjugate bound is proportional to amount of $\mathrm{Ab}$ in the sample

- Add substrate of enzyme

- Amount of color is proportional to amount of $\mathrm{Ab}$ in patient's sample.

However, ELISA technique in some cases is regarded as time consuming and it needs special equipment to run the assay (not portable). Thus many techniques have been developed to fasten the process such as that of Xin et al., 2009 [38], where he developed a chemiluminescence enzyme immunoassay using magnetic particles to monitor $17 \beta$-estradiol (E2) in environmental water samples. Another technique is using simple/rapid (S/R) test. The development of simple/rapid S/R tests has been extended from pregnancy detection of HIV antibodies in whole blood in addition to serum and plasma [39].

\subsection{Antibiotics Production}

Penicillins are the most widely used $\beta$-lactam antibiotics, with a share of about $19 \%$ of the estimated world-wide antibiotic market (Table 3) [8,27].

Production of antibiotics is one of the key areas in the field of applied microbiology. The conventional method of production is in stirred tank batch reactors. Since it is a no growth associated process, it is difficult to produce the antibiotic in continuous fermentations with free-cells. But it is a suitable case for cell immobilization, since growth and metabolic production can be uncoupled without affecting metabolite yields. Therefore, several attempts have been made to immobilize various microbial species on different supports matrices for antibiotic production. The most widely studied system is the production of penicillin $\mathrm{G}$ using immobilized cells of Penicillium chrysogenum [4]. In a recent study by Elnashar et al., they were successful to covalently immobilize pencillin $\mathrm{G}$ acylase on carrageenan modified gels with retention of $100 \%$ activity after 20 reuses [9].

\subsection{Medical Applications Particularly in Therapy}

Medical applications of immobilized enzymes include diagnosis and treatment of diseases, among those enzyme replacement therapies, as well as artificial cells and organs, and coating of artificial materials for better biocompatibility [41]. Examples of potential medical uses of immobilized enzyme systems are listed below. For more applications, readers are encouraged to read the review article of Soetan et al., 2010 [42], where he reviewed the biochemical, biotechnological and other applications of enzymes.

- Asparaginase (3.5.1.1) for leukemia

- Arginase (3.5.3.1) for cancer

- Urease (3.5.1.5) for artificial kidney, uraemic disorders

- Glucose oxidase (1.1.3.4) for artificial pancreas

- Carbonate dehydratase (4.2.1.1) and catalase (1.11.1.6) for artificial lungs

- Glucoamylase (3.2.1.3) for glycogen storage disease

- Glucose-6-phosphate dehydrogenase (1.1.1.49) for glucose-6-phosphate dehydrogenase deficiency

- Xanthine oxidase (1.1.3.22) for Lesch-Nyhan disease

- Phenylalanine ammonia lyase (4.3.1.5) for phenylketonuria

- Urate oxidase (1.7.3.3) for hyperuricemia

- Heparinase (4.2.2.7) for extracorporeal therapy procedures

In addition to the above applications, we will focus the light on some important applications as solving the problem of lactose Intolerant people, production of fructose for diabetics and for people on diet regimen, and treatment of rheumatoid arthritis and joint diseases. 


\subsubsection{Solving the Problem of Lactose Intolerant People}

$\beta$-galactosidase is widely used in milk industries for hydrolysis of lactose to glucose and galactose. Lactose is the main carbohydrate contained in milk at a concentration between $5 \%$ and $10 \%(\mathrm{w} / \mathrm{v})$ depending on the source of milk [43]. Lactose could also be found in whey permeate at higher concentrations. The consumption of foods with a high content of lactose is causing a medical problem for almost $70 \%$ of the world population, especially in the developing countries, as the naturally present enzyme ( $\beta$-galactosidase) in the human intestine, loses its activity during lifetime [44]. Undigested lactose in chyme retains fluid, bacterial fermentation of lactose results in production of gases, diarrhoea, bloating and abdominal cramps after consumption of milk and other dairy products.

Unfortunately, there is no cure to "lactose intolerance". This fact, together with the relatively low solubility and sweetness of lactose, has led to an increasing interest in the development of industrial processes to hydrolyze the lactose contained in dairy products (milk and whey) with both the free and immobilized conditions [45]. The studies have shown that glucose and galactose, the two monosaccharides hydrolosates of lactose (products hydrolyzed from lactose), are four times sweeter than lactose, more soluble, more digestible [46], and can be consumed by 'lactose intolerant' people. Interesting results of immobilized $\beta$-galactosidase on thermostable biopolymers of grafted carrageenan were obtained recently by Elnashar and Yassin [10,13] .

\subsubsection{Fructose for Diabetics and for People on Diet Regimen}

People on diet regimen and patients suffering from diabetes are highly recommended to consume fructose rather than any other sugar. Fructose can be produced from starch by enzymatic methods involving $\alpha$-amylase, amyloglucosidase, and glucose isomerase, resulting in the production of a mixture consisting of oligosaccharides $(8 \%)$, fructose (45\%), and glucose (50\%) [47]. However, separation of fructose from this high content fructose syrup is costly and thus makes this method uneconomical. In industries, inulinases are used to produce $95 \%$ of pure fructose after one step of the enzymatic hydrolysis of inulin. Industrial inulin hydrolysis is carried out at $60{ }^{\circ} \mathrm{C}$ to prevent microbial contamination and also because it permits the use of higher inulin substrate concentration due to increased solubility. Elnashar et al., 2009 and Danial et al., 2010, have succeeded recently to produce a thermostable inulinolytic immobilized enzyme, which would be expected to play an important role in food and chemical industries, in which fructose syrup is widely applied $[7,10]$.

\subsubsection{Treatment of Rheumatoid Arthritis and Joint Diseases}

Superoxide dismutase (SOD) and catalase (CAT) have been encapsulated in biodegradable microspheres (MS) to obtain suitable sustained protein delivery [48]. A modified water/oil/water double emulsion method was used for poly (D, L-lactide-co-glycolide) (PLGA) and poly (D, L-lactide) PLA MS preparation co-encapsulating mannitol, trehalose, and PEG400 for protein stabilization. SOD release from PLGA MS may be potentially useful for long-term sustained release of the enzyme for the treatment of rheumatoid arthritis or other intra-articular and joint diseases (inflammatory manifestation).

\subsection{Non Medical Applications of Immobilized Enzymes}

\subsubsection{Treatment of Pesticide-Contaminated Waste}

Application of pesticide in agriculture serves to lower the cost of production, increase crop yields, provide better quality produce and also reduce soil erosion. Although pesticides are toxic and have adverse effect on human health and the environment, their use is inevitable in many cases as an effective means of controlling weeds, insect, and fungus, parasitic and rodent pests. One of the most important technologies to be applied for this approach is immobilized enzyme. The immobilized enzyme is capable of breaking down a range of pesticide-contaminated waste as organophosphate insecticides $[49,50]$.

\subsubsection{Neutralizing Dangerous Chemical Gases or Vapors}

The use of immobilized enzymes in the national security arena has shown to be promising. For example, they could include infiltrating items such as air filters, masks, clothing, or bandages with the concentrated immobilized enzymes to neutralize dangerous chemical gases or vapors [51].

\subsection{Purification of Proteins}

Protein purification is an important objective in industrial enzymes in order to increase the enzyme's specific activity and to obtain an enzyme in its pure form for a specific goal. Affinity ligands is the most used technique for purification of target molecules as it can reduce the number of chromatographic steps in purification procedures to one or two steps. Immobilization of affinity ligands to an insoluble support can be a powerful tool in isolation of particular substances (e.g. protein) from a complex mixture of proteins. Some examples of affinity ligands are immobilized carbohydrate-binding proteins and immobilized metal ions. Another technique for protein purification is using Electric field gradient focusing (EFGF). For 
more information on the principles and methods of protein purification, readers should refer to the "Handbook: Purifying challenging proteins: principles and methods” in 2007 [52].

\subsubsection{Immobilized Carbohydrates-Binding Proteins}

Purification of proteins could be performed using immobilized carbohydrates such as mannose, lactose and melibiose. For example, immobilized lactose on sepharose $4 \mathrm{~B}^{\mathrm{TM}}$ will be selective for purification of lactase from a mixture of other proteins. More information on this technique can be found in the book of Hermanson et al., 1992 "Immobilized affinity ligand techniques" [53].

\subsubsection{Electric Field Gradient Focusing (EFGF)}

Electric field gradient focusing is a member of the family of equilibrium gradient focusing techniques (e.g gel electrophoresis). It depends on an electric field gradient and a counter-flow to focus, concentrate and separate charged analytes, such as peptides and proteins. Since analytes with different electrophoretic mobilities have unique equilibrium positions, EFGF separates analytes according to their electrophoretic mobilities, similar to the way isoelectric focusing (IEF: electrophoresis is a $\mathrm{pH}$ gradient where the cathode is at a higher $\mathrm{pH}$ value than the anode) separates analytes according to isoelectric points. The constant counter flow is opposite to the electrophoretic force that drives the analytes. When the electrophoretic velocity of a particular analyte is equal and opposite to the velocity of the counter flow, the analyte is focused in a narrow band because at this position the net force on it is zero.

However, EFGF avoids protein precipitation that often occurs in IEF when proteins reach their isoelectric points and, therefore, can be applied to a broad range of proteins. Sun (2009) [54] in his Ph.D. thesis demonstrated that protein concentration exceeding 10,000-fold could be concentrated using such devices.

\subsection{Extraction of Biomolecules Using Magnetic Particles}

The traditional methods for biomolecules purification such as centrifugation, filtration, and chromatography can today be replaced by the use of magnetic particles. They are reactive supports for biomolecules capturing. Their use is simple, fast, and efficient for the extraction and purification of biomolecules. In the biomedical Weld, numerous publications deal with the use of magnetic particles for biomolecule extraction [55], cell sorting [56], and drug delivery [57]. Magnetic beads are widely used in molecular biology [58], medical diagnosis [59], and medical therapy [55].

The major application concerns the extraction of biomolecules such as proteins [60], antibodies, and nucleic acids [61]. Magnetic beads carrying antibodies are also used for specific bacteria [55] and virus captures [58]. Krupey in 1994 [62] patented a method for virus capture process. The method was based on interactions between viruses and anionic polymers, leading to the precipitation of complexes by charge neutralization. After the capture step, viruses were extracted by centrifugation. At the current time, to our knowledge, only one method using magnetic beads has been published recently [63]. In these studies, some DNA and RNA viruses were concentrated more than 100 and 1000 times, respectively, using polyethyleneimine (PEI)1-conjugated magnetic beads.

\subsection{Heavy Metals Removal}

Heavy metal pollution is an environmental problem of worldwide concern. Several industrial wastewater streams may contain heavy metals such as; $\mathrm{Pb}, \mathrm{Cr}, \mathrm{Cd}$, $\mathrm{Ni}, \mathrm{Zn}, \mathrm{As}, \mathrm{Hg}, \mathrm{Cu}, \mathrm{Ag}$. Traditionally, precipitation, solvent extraction, ion-exchange separation and solid phase extraction are the most widely used techniques to eliminate the matrix interference and to concentrate the metal ions. Many materials have been used to remove them such as sorbents [64] (e.g. silica, chitosan, sponge, etc) and biosorbents (e.g. immobilized algae) [65].

Biosorbents: can be defined as the selective sequestering of metal soluble species that result in the immobilization of the metals by microbial cells such as cyanobacteria. It is the physicochemical mechanisms of inactive (i.e. non-metabolic) metal uptake by microbial biomass. Metal sequestering by different parts of the cell can occur via various processes: complexation, chelation, coordination, ion exchange, precipitation, reduction. Size of immobilized bead for metals removal is a crucial factor for use of immobilized biomass in bio-sorption process. It is recommended that beads should be in the size range between 0.7 and $1.5 \mathrm{~mm}$, corresponding to the size of commercial resins meant for removing metal ions. Abdel Hameed and Ebrahim, 2007 [63] in their review article, has revealed some of the immobilized algae on different matrices that have potential in heavy metals removal due to its high uptake capacity and abundance.

\subsection{Production of Biosensors}

Biosensors are chemical sensors in which the recognition system utilizes a biochemical mechanism [66]. A biosensor is a sensing device made up of a combination of a specific biological element and a transducer. The "specific biological element" such as antibodies [67], enzymes [68], bacteria [69,70] and DNA [71] recognizes a specific analyte such as pollutions (toxicity caused by pesticides, phenols, mercury, arsenic, etc) and the changes in the biomolecules are usually converted into electrical signal (which is in turn calibrated to a certain 
scale) by a transducer.

\subsection{Production of Biodiesel}

The idea of using biodiesel as a source of energy is not new [72], but it is now being taken seriously because of the escalating price of petroleum and, more significantly, the depletion of fossil fuels (oil and gas) within the next 35 years and the emerging concern about global warming that is associated with burning fossil fuels [73]. Biodiesel is much more environmentally friendly than burning fossil fuels, to the extent that governments may be moving towards making biofuels mandatory [74]. The global market survey of biodiesel has shown a tremendous increase in its production.

Biodiesel is made by chemical combination of any natural oil or fat with an alcohol such as methanol and a catalyst (e.g. lipases) for the transesterification process. Transesterification is catalyzed by acids, alkalis [75] and lipase enzymes [76]. Use of lipases offers important advantages as it is more efficient, highly selective, involves less energy consumption (reactions can be carried out in mild conditions), and produces less side products or waste (environmentally favorable). However, it is not currently feasible because of the relatively high cost of the catalyst [77].

On the industrial level, a number of methods for the immobilization of lipases on solid supports have been reported [78]. Commercially available lipases are supplied both as lyophilised powders, which contain other components in addition to the lipase [79]. The immobilized lipases most frequently used for biodiesel production are lipase B from Candida Antarctica [80]. This is supplied by Novozymes under the commercial name Novozym $435{ }^{\circledR}$ (previously called SP435) and is immobilized on an acrylic resin. The Mucor miehei commercial lipase (Lipozyme IM60 - Novozym) immobilized on a macroporous anionic exchange resin has also been extensively used for the same purpose [81].

\subsection{Life Detection and Planetary Exploration}

Analytical techniques based on mass spectrometry have been traditionally used in space science. Planetary exploration requires the development of miniaturized apparatus for in situ life detection. Recently, a new approach is gaining acceptance in the space science community: the application of the well-known, highly specific, antibody-antigen affinity interaction for the detection and identification of organics and biochemical compounds. Antibody microarray technology allows scientists to look for the presence of thousands of different compounds in a single assay and in just one square centimeter. The detection of organic molecules of unambiguous biological origin is fundamental for the confir- mation of present or past life.

Preservation of biomarkers on the antibody stability under space environments, smaller biomolecules, such as amino acids, purines, and fatty acids, are excellent biomarkers in the search for life on Mars, but they may be much less resistant to oxidative degradation. Recent work by Kminek and Bada, 2006 [82] showed that amino acids can be protected from radiolysis decomposition as long as they are shielded adequately from space radiation. They estimated that it is necessary to drill to a depth of 1.5 to $2 \mathrm{~m}$ to detect the amino acid signature of life that became extinct about three billion years ago. A microfabricated capillary [83] electrophoresis device (kind of new immobilization technology) for amino acid chirality determination was developed for extraterrestrial exploration [84]. Recently, antibody microarray, a new immobilization technology that kept the stability of antibody under space environment allowed it to be applied for planetary exploration Exomars mission [85].

\section{Recent Advances in Supports and Technologies used in Enzyme Immobilization}

In the search for suitable supports for enzyme immobilization, it was found that physical and chemical properties (e.g. pore size, hydrophilic/hydrophobic balance, aquaphilicity and surface chemistry) of support could exert effect on enzyme immobilization and its catalytic properties [86]. Thus there was a need for new immobilization techniques/supports to avoid such shortcomings [19]. The following are some examples of the recent carriers and technologies used for enzyme immobilization.

\subsection{New Carriers Used in Immobilization}

\subsubsection{New Carriers Used in Immobilization}

Over the last few years, mesoporous support such as silica and silicates having pore size of $2-50 \mathrm{~nm}$ has been developed and being considered as one of the most promising carriers for enzyme immobilization [87-91]. The exploitation of novel carriers that enable high enzyme loading and activity retention has become the focus of recent attention [92]. The large surface areas and greater pore volumes of these materials could enhance the loading capacity of an enzyme and the large pores in the support facilitate transport of substrate and product [93].

Functional mesoporous material resulted in exceptionally high immobilization efficiency with enhanced stability, while conventional approaches yielded far lower immobilization efficiency [94]. Additionally, the increase in the thermal stability of immobilized enzyme indicated that protein inside a confined space could be stabilized by some folding forces which did not exist in proteins in bulk solutions [95]. Confinement of the support nanopore 
could be similar to the macromolecular crowding [96], and could also stabilize the enzyme at high temperature.

Nanoporous gold [97] and nanotube [98,99] have also been used to immobilize enzymes. Most of the obtained immobilized enzymes were used in the electrode preparation and biosensor applications. The modified porous gold electrode shows an overall increased signal, and therefore a better detection limit and higher sensitivity when used as sensors.

\subsubsection{Magnetic Hybrid Support}

The use of magnetic supports for enzyme immobilization enables a rapid separation in an easily stabilized fluidized bed reactor for continuous operation of enzyme. It can also reduce the capital and operation costs [100]. Due to the functionalization [101] of enzyme and its suitable microenvironment, magnetic materials were often embedded in organic polymer or inorganic silica to form hybrid support [102]. Recently, because of the low enzyme loading on the conventional magnetic beads, further attention was paid to the magnetic mesoporous support [103]. Magnetite mesoporous silica hybrid support was fabricated by the incorporation of magnetite to the hollow mesoporous silica shells, which resulted in the perfect combination of mesoporous materials properties with magnetic property. The produced hybrid support has shown to improve the enzyme immobilization [104].

\subsection{New Technologies for Enzyme Immobilization}

\subsubsection{Single Enzyme Nanoparticles}

In the field of industrial enzymes, there is a great research for improving the enzyme stability under harsh conditions. As an innovative way of enzyme stabilization, "single-enzyme nanoparticles (SENs)" technology was rather attractive because enzymes in the nanoparticle exhibited very good stability under harsh conditions [107] have developed armored SENs that surround each enzyme molecule with a porous composite organic/ inorganic network of less than a few nanometers thick. They significantly stabilized chymotrypsin and trypsin and the protective covering around chymotrypsin is so thin and porous that a large mass transfer limitation on the substrate could not take place.

Yan et al. (2006) [106] provided a simple method that yields a single enzyme capsule with enhanced stability, high activity and uniformed size. The 2-step procedure including surface acryloylation and in situ aqueous polymerization to encapsulate a single enzyme in nanogel to provide robust enzymes for industrial biocatalysis. The immobilized horseradish peroxidase (HRP) exhibited similar biocatalytic behavior ( $\mathrm{Km}$ and $\mathrm{kcat}$ ) to the free enzyme. However, the immobilization process signifi- cantly improved the enzymels stability at high temperature in the presence of polar organic solvent.

\subsubsection{Enzymatic Immobilization of Enzyme}

The use of green chemistry rather than using harsh chemicals is one of the main goals in enzyme industries to avoid the partial denaturation of enzyme protein. An emerging and novel technology is to fabricate solid protein formulations [108,109]. As model proteins, enhanced green fluorescent protein (EGFP) and glutathione S-transferase (GST) were tagged with a neutral Gln-donor substrate peptide for MTG (Leu-Leu-Gln-Gly, LLQG-tag) at their C-terminus and immobilized onto the casein-coated polystyrene surface [108].

Luciferase (Luc) and glutathione-S-transferase (GST) ybbR-fusion proteins were immobilized onto PEGA resin retaining high levels of enzyme activity using phosphopantetheinyl transferase (Sfp) mediating site-specific covalent immobilization [109]. In general, the Sfp-catalyzed surface ligation is mild, quantitative and rapid, occurring in a single step without prior chemical modification of the target protein.

\subsubsection{Microwave Irradiation}

The use of porous supports for immobilization of enzymes is difficult to distribute because of diffusion limitations [110] and they often remain only on external channel [111]. For enzymes having large dimensions, such as penicillin acylase (PA), the mass transfer is even slower. The immobilization of such enzyme to porous materials can prove tedious using conventional techniques [112].

Wang et al., 2008b \& 2009a [95,113] have recently succeeded to immobilize papain and PA using the adsorption technique into the mesocellular siliceous foams (MCFs) using microwave irradiation technology. Reaction time of 80 and $140 \mathrm{~s}$ were enough for papain and PA to attach on the wall of MCFs, respectively. The activities of papain and penicillin acylase immobilized with microwave-assisted method were 779.6 and $141.8 \mathrm{U} / \mathrm{mg}$, respectively. In another experiment, macromolecules crowding was combined with small molecular quenching to perfect microwave-assisted covalent immobilization [113].

\subsubsection{Photoimmobilization Technology}

In the field of immobilization of biomolecules, potential applications of photoimmobilization using nitrene groups could take place. Nitrene groups have a property of insertion into $\mathrm{C}-\mathrm{H}$ bond. When photoreactive polymer and horseradish peroxidase or glucose oxidase are exposed to ultraviolet (UV) light at $365 \mathrm{~nm}$, the reactive nitrene immobilizes the protein molecules in 10 to $20 \mathrm{~min}$ through covalent bonding [114]. Horseradish peroxidase 
(HRP) and glucose oxidase (GOD) have been immobilized onto the photoreactive cellulose membrane by the ultraviolet and sunlight [115]. They found that sunlight intensity required for optimum immobilization was 21,625 lux beyond which no appreciable increase in immobilization was observed. Moreover, sunlight exposure gave better immobilization compared to $365 \mathrm{~nm} \mathrm{UV}$ light.

\subsubsection{Ionic Liquids}

Ionic liquids, the green solvents for the future, are composed entirely of ions and they are salts in the liquid state. In the patent and academic literature, the term "ionic liquid" now refers to liquids composed entirely of ions that are fluid around or below $100^{\circ} \mathrm{C}$ (e.g. ethanolamine nitrate, m.p. $52-55^{\circ} \mathrm{C}$ ). The date of discovery of the "first" ionic liquid is disputed, along with the identity of the discoverer. Room-temperature ionic liquids are frequently colorless, fluid and easy to handle [116].

Versatile biphasic systems could be formed by controlling the aqueous miscibility of ionic liquid [117]. Based on a biphasic catalytic system where the enzyme is immobilized into an ionic liquid (IL), Mecerreyes and co-workers [118] have reported a new method which allows recycling and re-using of the HRP enzyme in the biocatalytic synthesis of PANI. The HRP enzyme was dissolved into the IL 1-butyl-3-methylimidazolium hexafluorophosphate and the IL/HRP phase acts as an efficient biocatalyst and can be easily recycled and reused several times. Due to the immiscibility between the IL and water, the immobilized HRP could be simply recovered by liquid/ liquid phase separation after the biocatalytic reaction $[119,120]$. Although this new method is faster and easier than the classical immobilization of HRP into solid supports, it would not be widely applied to the industrial production in the coming future because of the ionic liquids' expenses.

\section{Recommendation for the Future of Immobilization Technology}

At present, a vast number of methods of immobilization are currently available. Unfortunately, there is no a universal enzyme support, i.e. the best method of immobilization might differ from enzyme to enzyme, from application to application and from carrier to carrier. Accordingly, the approaches currently used to design robust industrial immobilized enzymes are, without exception, labeled as "irrational", because they often result from screening of several immobilized enzymes and are not designed. As a consequence, some of the industrial enzymes are working below their optimum conditions.

Recently, Cao L. (2005) [5] in his book "Carrier bound immobilized enzymes" tackled this problem as he surmised that the major problem in enzyme immobilization is not only the selection of the right carrier for the enzyme immobilization but it is how to design the performance of the immobilized enzyme.

The author of this review article is suggesting from his point of view as he is working in that field for the last ten years to follow these steps in order to get to this goal in the shortest time:

1- build a data base containing all information on the available biomolecules (enzymes, antibodies, etc) and carriers (organic, inorganic, magnetic hybrid, ionic liquids, etc) then

2- use the dry lab (bioinformatics) to validate the probability of success and the efficiency of the immobilization process then

3- starting the experiment in the wet lab.

The author believes that if this strategy could be performed, we should expect immobilized molecules working at their optimum conditions, with higher stability and efficiency, which will save money, time and effort for the prosperity of human being.

\section{Acknowledgements}

The author would like to thank the Centre of Excellence for Advanced Sciences, NRC, Egypt, the Research and Development Innovation (RDI) program and the Science and Technology Development Fund STDF/IMC for supporting this work, and highly appreciates the efforts of Mrs Joanne Yachou for her contribution towards editing.

\section{REFERENCES}

[1] H. Buyukgungor and L. Gurel, "The Role of Biotechnology on the Treatment of Wastes," African Journal of Biotechnology, Vol. 8, No. 25, 2009, pp. 72537262.

[2] Z. T. Yu-Qung, S. Mei-Lin, Z. Wei-De, D. Yu-Zhen, M. Yue and Z. Wen-Ling, "Immobilization of L-Asparaginase of the Microparticles of the Natural Silk Serum Protein and Its Characters," Biomaterials, Vol. 25, No. 17, 2003, pp. 3151-3759.

[3] K. Kierek-Pearson and E. Karatan, "Biofilm Development in Bacteria," Advances in Applied Microbiology, Vol. 57, 2005, pp. 79-111.

[4] B. Carpentier and O. Cerf, "Biofilms and Their Consequences, with Particular Reference to Hygiene in the Food Industry," Journal of Applied Bacteriology, Vol. 75, No. 6, 1993, pp. 499-511.

[5] L. Cao and R. D. Schmid, "Carrier-Bound Immobilized Enzymes: Principles, Application and Design," WILEYVCH Verlag GmbH \& Co, Weinheim, 2005.

[6] M. Ayala and E. Torres, "Enzymatic Activation of Alkanes: Constraints and Prospective," Applied Catalysis A: General, Vol. 272, No. 1-2, 2004, pp. 1-13.

[7] E. N. Danial, M. M. Elnashar and G. E. Awad, "Immobilized Inulinase on Grafted Alginate Beads Prepared by the 
One-Step and the Two-Steps Methods Indus," Chemical Engineering Research, Vol. 49, No. 7, 2010, pp. 31203125.

[8] M. M. Elnashar, "Chapter in a Book Entitled "Low-Cost Foods and Drugs Using Immobilized Enzymes on Biopolymers," Book entitled Biopolymers, published by www.sciyo.com (In Press), 2010.

[9] M. M. Elnashar, A. M. Yassin and T. Kahil, "Novel Thermally and Mechanically Stable Hydrogel for Enzyme Immobilization of Penicillin G Acylase Via Covalent Technique," Journal of Applied Polymer Science, Vol. 109, No. 6, 2008, pp. 4105-4111.

[10] M. M. Elnashar, E. N. Danial and G. E. Awad, "Novel Carrier of Grafted Alginate for Covalent Immobilization of Inulinase," Industrial \& Engineering Chemistry Research, Vol. 48, No. 22, 2009, pp. 9781-9785.

[11] M. M. Elnashar, A. M. Yassin, A. A. Abdel Moneim and E. M. Abdel Bary, "Surprising Performance of Alginate Beads for the Release of Low Molecular Weight Drugs," Journal of Applied Polymer Science, Vol. 116, No. 5, 2010, pp. 3021-3126.

[12] M. M. Elnashar and A. M. Yassin, "Covalent Immobilization of B-Galactosidase on Carrageenan Coated Chitosan," Journal of Applied Polymer Science, Vol. 114, No. 1, 2009a, pp. 17-24.

[13] M. M. Elnashar and A. M. Yassin, "Lactose Hydrolysis by $\beta$-Galactosidase Covalently Immobilized to Thermally Stable Biopolymers," Applied Biochemistry and Biotechnology, Vol. 159, No. 2, 2009b, pp. 426-437.

[14] M. E. Mansour, M. M. Elnashar and M. E. Hazem, “Amphoteric Hydrogels Using Template Polymerization Technique," Journal of Applied Polymer Science, Vol. 106, No. 6, 2007, pp. 3571-3580.

[15] B. Katzbauer, M. Narodoslawsky, A. Moser, "Classification System for Immobilization Techniques," BioProcess Engineering, Vol. 12, No. 4, 1995, pp. 173-179.

[16] T. Tosa, T. Mori, N. Fuse and I. Chibata, "Studies on Continuous Enzyme Reactions Part V Kinetics and Industrial Application of Aminoacylase Column for Continuous Optical Resolution of Acyl-Dl Amino Acids," Biotechnology and Bioengineering, Vol. 9, No. 4, 1967, pp. 603-615.

[17] B. Menaa, C. Torres, M. Herrero, V. Rives, A. R. W. Gilbert and D. K. Eggers, "Protein Adsorption to Organically-Modified Silica Glass Leads to a Different Structure Than Sol-Gel Encapsulation," Biophysical Journal, Vol. 95, No. 8, 2008a, pp. 51-53.

[18] S. Çetinus, E. Sahin and D. Saraydin, "Preparation of $\mathrm{Cu}(\mathrm{II})$ Adsorbed Chitosan Beads for Catalase Immobilization," Food Chemistry, Vol. 114, No. 3, 2009, pp. 962969.

[19] T. Xie, A. Wang, L. Huang, H. Li, Z. Chen, Q. Wang and $X$. Yin, "Review: Recent Advance in the Support and Technology Used in Enzyme Immobilization," African Journal of Biotechnology, Vol. 8, No. 19, 2009, pp. 47244733.

[20] G. F. Bickerstaff, "Impact of Genetic Technology on
Enzyme Technology," Biotechnology \& Genetic Engineering Reviews, Vol. 15, No. 1, 1995, pp. 13-30.

[21] A. Riaz, S. Qader, A. Anwar and S. Iqbal, "Immobilization of a Thermostable á-amylase on Calcium Alginate Beads from Bacillus Subtilis KIBGE-HAR," Australian Journal of Basic and Applied Sciences, Vol. 3, 2009, p. 2883.

[22] A. Groboillot, D. K. Boadi, D. Poncelot and R. J. Neufled, "Immobilization of Cells for Application in the Food Industry," Critical Reviews in Biotechnology, Vol. 14, No. 2, 1994, pp. 75-107.

[23] J. S. Patil, M. V. Kamalapur, S. C. Marapur and D. V. Kadam, "Ionotropic Gelation and Polyelectrolyte Complexation: The Novel Techniques to Design Hydrogel Particulate Sustained, Modulated Drug Delivery System: A Review," Digest Journal of Nanomaterials and Biostructures, Vol. 5, 2010, p. 241.

[24] B. Menaa, M. Herrero, V. Rives, M. Lavrenko and D. K. Eggers, "Favorable Influence of Hydrophobic Surfaces on Protein Structure in Porous Organically-Modified Silica Glasses," Biomaterials, Vol. 29, No. 18, 2008b, pp. 27102718.

[25] B. Menaa, Y. Miyagawa, M. Takahashi, M. Herrero, V. Rives, F. Menaa and D. K. Eggers, "Bioencapsulation of Apomyoglobin in Nanoporous Organosilica Sol-Gel Glasses: Influence of the Siloxane Network on the Conformation and Stability of a Model Protein," Biopolymers, Vol. 91, No. 11, 2009, pp. 895-906.

[26] B. Menaa, F. Menaa, C. Aiolfi-Guimaraes and O. Sharts, "Silica-Based Nanoporous Sol-Gel Glasses: From Bioencapsulation to Protein Folding Studies," International Journal of Nanotechnology, Vol. 7, No. 1, 2010, pp. 1-45.

[27] M. M. Elnashar, "Development of a Novel Matrix for the Immobilization of Enzymes for Biotechnology," Leeds University, UK, 2005.

[28] M. M. Elnashar, P. A. Millner, A. F. Johnson and T. D. Gibson, "Parallel Plate Equipment for Preparation of Uniform Gel Sheets," Biotechnology Letters, Vol. 27, No. 10, 2005, pp. 737-739.

[29] C. C. Lin and A. T. Metters, "Hydrogels in Controlled Release Formulations: Network Design and Mathematical Modeling," Advanced Drug Delivery Reviews, Vol. 58, No. 12-13, 2006, pp. 1379-1408.

[30] E. J. Pollauf and D. W. Pack, "Use of Thermodynamic Parameters for Design of Double-Walled Microsphere Fabrication Methods," Biomaterials, Vol. 27, No. 14, 2006, pp. 2898-2906.

[31] D. W. Pack, A. S. Hoffman, S. Pun and P. S. Stayton, "Design and Development of Polymers for Gene Delivery," Nature Reviews Drug Discovery, Vol. 4, 2005, pp. 581-593.

[32] A. C. R. Grayson, I. S. Choi, B. M. Tyler, P. P. Wang and B. H. Michael, "Multi-Pulse Drug Delivery from a Resorbable Polymeric Microchip Device," Nature Materials journal Cima, Vol. 2, No. 11, 2003, pp. 767-772.

[33] Y. H. Kim, I. C. Kwon, Y. H. Bae and S. W. Kim, "Saccharide Effect on the Cloud Point of Thermosensitive 
Polymers," Macromolecules, Vol. 28, No. 4, 1995, pp. 939-944.

[34] P. Sona, "Nanoparticulate Drug Delivery Systems for the Treatment of Diabetes," Digest Journal of Nanomaterials and Biostructures, Vol. 5, No. 2, 2010, pp. 411-418.

[35] M. Yu, Y. Jeong, J. Park, S. Park, J. Kim, J. Min, K. Kim and S. Jon, "Drug-Loaded Superparamagnetic Iron Oxide Nanoparticles for Combined Cancer Imaging and Therapy in vivo," Angewandte Chemie International Edition, Vol. 47, No. 29, 2008, pp. 5362-5365.

[36] M. Kettering, H. Zorn, S. Bremer-Streck, H. Oehring, M. Zeisberger, C. Bergemann, R. Hergt, J. Halbhuber, A. Kaiser and I. Hilger, "Characterization of Iron Oxide Nanoparticles Adsorbed with Cisplatin for Biomedical Applications," Physics in Medicine and Biology, Vol. 54, 2009, pp. 5109-5121.

[37] M. Farre, M. Kuster, R. Brix, F. Rubio, M.-J. L. d. Alda and D. Barcelo, "Comparative Study of an Estradiol Enzyme-Linked Immunosorbent Assay Kit, Liquid Chromatography-Tandem Mass Spectrometry, and Ultra Performance Liquid Chromatography-Quadrupole Time of Flight Mass Spectrometry for Part-Per-Trillion Analysis of Estrogens in Water Samples," The Journal of Chromatography A, Vol. 1160, No. 1-2, 2007, pp. 166-175.

[38] T. Xin, X. Wang, H. Jin, S. Liang, J. Lin and Z. Li, "Development of Magnetic Particle-Based Chemiluminescence Enzyme Immunoassay for the Detection of $17 \beta$-Estradiol in Environmental Water," Applied Biochemistry and Biotechnology, Vol. 158, No. 3, 2009, pp. 582-594.

[39] World Health Organization (WHO), "HIV Simple/Rapid Assays: Operational Characteristics (Phase I)," 2002, http://www.who.int/3by5/en/simplerapidassays.pdf

[40] M. Ogaki, K. Sonomoto, H. Nakajima and A. Tanaka, "Continuous Production of Oxytetracycline by Immobilized Growing Streptomyces Rimosus Cells," Applied Microbiology and Biotechnology, Vol. 24, 1986, pp. 6-11.

[41] A. K. Piskin, "Therapeutic Potential of Immobilized Enzymes," NATO ASI Series, Series E, Vol. 252, 1993, p. 191.

[42] K. Soetan, O. Aiyelaagbe and C. Olaiya, "Review of the Biochemical, Biotechnological and Other Applications of Enzymes," African Journal of Biotechnology, Vol. 9, No. 4, 2010, pp. 382-393.

[43] J. A. Ordoñez, M. A. Cambero, L. Fernandez, M. L. Garcia, G. Garcia and L. Hoz, "Componentes de los Alimentos y procesos. Tecnologia de los Alimentos," Editorial Sintesis, Madrid, Spain, 1998.

[44] M. Richmond, J. Gray and C. Stine, "Beta-galactosidase: Review of Recent Research Related to Technological Application, Nutritional Concerns, and Immobilization," The Journal of Dairy Science, Vol. 1759, 1981, p. 64.

[45] J. H. German, "Applied Enzymology of Lactose Hydrolysis," In Milk Powders for the Future, p. 81.

[46] S. Sungur and U. Akbulut, "Immobilization of $\beta$-galactosidase onto Gelatin by Glutaraldehyde and Chromium (III) Acetate," Journal of Chemical Technol- ogy \& Biotechnology, (Oxford, Oxfordshire) Vol. 59, No. 3, 1994, pp. 303-306.

[47] P. Gill, R. Manhas and P. Singh, "Hydrolysis of Inulin by Immobilized Thermostable Extracellular Exoinulinase from Aspergillus Fumigatus," Journal of Food Engineering, Vol. 76, No. 3, 2006, pp. 369-375.

[48] S. Giovagnoli, "Biodegradable Micropheres as Carriers for Native Superoxide Dismutase and Catalase Delivery," AAPS Pharmaceutical Science Technology, Vol. 5, No. 4, 2004, p. 51.

[49] I. Horne, T. D. Sutherland, R. L. Harcourt, R. J. Russell and J. G. Oakeshott, "Identification of an (Organophosphate Degradation) Gene in an Agrobacterium Isolate," Applied and Environmental Microbiology, Vol. 68, No. 7, 2002, pp. 3371-3376.

[50] F. Sharmin, S. Rakshit, H. Jayasuriya, "Enzyme Mmobilization on Glass Surfaces for the Development of Phosphate Detection Biosensors," Agricultural Engineering International: the CIGR Ejournal. Manuscript FP 06019 , Vol. IX. April 2007.

[51] E. Ackerman and C. Lei, "Immobilizing Enzymes for Useful Service," 2008. http//www.google

[52] Hand book from GE Healthcare, "Purifying Challenging Proteins: Principles and Methods," General Electric Co, USA, 2007.

[53] G. Hermanson, A. Mallia and P. Smith, "Immobilized Affinity Ligand Techniques," Academic Press Incorporation, New York, 1992.

[54] X. Sun, "Polymeric Microfluidic Devices for Bioanalysis," Brigham Young University, China, 2009.

[55] T. Delair and F. Meunier, "Amino-Containing Cationic Latex Oligo-Conjugates: Application to Diagnostic Test Sensitivity Enhancement," Colloids and Surface, Vol. 153, No. 1-3, 1999, pp. 341-353.

[56] J. T. Kemshead, J. G. Treleaven, F. M. Gibson, J. Ugallstad, A. Rembaum and T. Philip, "Removal of Malignant Cells from Marrow Using Magnetic Microspheres And Monoclonal Antibodies," Progress in Experimental Tumor Research, Vol. 29, 1985, pp. 249-245.

[57] R. Langer, "New methods of drug delivery," Science, Vol. 249, No. 4976, 1990, pp. 1527-1533.

[58] J. D. Andreadis and L. A. Chrisey, "Use of Immobilized Pcr Primer to Generate Covalently Immobilized Dnas for In Vitro Transcription/Translation Reaction," Nucleic Acids Research, Vol. 28, No. 2, 2000, p. e5.

[59] M. Myrmel, E. Rimstad and Y. Wasteson, "IMS of Norwalk-like Virus (Geno Group I) in Artificially Contaminated Environmental Water Samples," International Journal of Food Microbiology, Vol. 62, No. 1-2, 2000, pp. 17-26.

[60] X. Ding and Y. Jiang, "Adsorption/Desorption of Protein on Magnetic Particles Covered by Thermosensitive Polymers," Journal of Applied Polymer Science, Vol. 278, 2000, p. 459.

[61] S. Rouquier, B. J. Tracks, "Direct Selection of cDNAs Using Whole Chromosomes," Nucleic Acids Research, 
Vol. 23, No. 21, 1995, pp. 4415-4420.

[62] J. Krupey, "Water Insoluble Cross-Linked Acid Composition," United States Patent, Vol. 5, No. 294, 1994, p. 681.

[63] A. Ifiata, K. Satoh, M. Murata, M. Hikata, T. Hayakawa and T. Yamaguchi, "Virus Concentration Using Sulfonated Magnetic Beads to Improve Sensitivity in Nucleic Acid Amplification Tests," Biological and Pharmaceutical Bulletin, Vol. 26, No. 8, 2003, pp. 1065-1069.

[64] H. M. Abdel and O. Ebrahim, "Review: Biotechnological Potential Uses of Immobilized Algae," International Journal of Agriculture and Biology, Vol. 9, 2007, p. 183.

[65] K. Shareef, "Sorbents for Contaminents Uptake from Aqueous Solutions," Part 1 Heavy Metals. World Journal of Agriculture Science, Vol. 5, 2009, p. 819.

[66] C. Jianrong, M. Yuqing, H. Nongyue, W. Xiaohua and L. Sijiao, "Nanotechnology and Biosensors," Biotechnology Advance, Vol. 22, No. 7, 2004, pp. 505-518.

[67] S. Rodriguez-Mozaz, S. Reder, M. J. Lopez de Alda, G. Gauglitz and D. Barcelo, "Simultaneous Multi-Analyte Determination of Estrone, Isoproturon and Atrazine in Natural Waters by the River Analyser (Riana), an Optical Immunosensor," Biosensors and Bioelectronics, Vol. 19, No. 7, 2004, pp. 633-640.

[68] C. Nistor, A. Rose, M. Farre, L. Stocia, U. Wollenberger, T. Ruzgas, D. Pfeiffer, D. Barcelo, L. Gorton and J. Emneus, "In-Field Monitoring of Cleaning Efficiency in Waste Water Treatment Plants Using Two Phenol-Sensitive Biosensors," Analytica Chimica Acta, Vol. 456, No, 1, 2002, pp. 3-17.

[69] J. C. Philp, S. Balmand, E. Hajto, M. J. Bailey, S. Wiles, A. S. Whiteley, A. K. Lilley, J. Hajto and S. A. Dunbar, "Whole Cell Immobilized Biosensors for Toxicity Assessment of a Wastewater Treatment Plant Treating Phenolics-Containing Waste," Analytica Chimica Acta, Vol. 487, No. 1, 2003, pp. 61-74.

[70] T. Petanen and M. Romantschuk, "Use of Bioluminescent Bacterial Biosensors as an Alternative Method for Measuring Heavy Metals in Soil Extracts," Analytica Chimica Acta, Vol. 456, No. 1, 2002, pp. 55-61.

[71] G. Marrazza, I. Chianella and M. Mascini, "Disposable DNA Electrochemical Biosensors for Environmental Monitoring," Analytica Chimica Acta, Vol. 387, No. 3, 1999, pp. 297-307.

[72] S. Sawayama, S. Inoue, Y. Dote and S. Y. Yokoyama, " $\mathrm{CO}_{2}$ Fixation and Oil Production through Microalga," Energy Conversion and Management, Vol. 36, No. 6-9, 1995, pp. 729-731.

[73] M. Gavrilescu and Y. Chisti, "Biotechnology: A Sustainable Alternative for Chemical Industry," Biotechnology Advance, Vol. 23, No. 7-8, 2005, pp. 471-499.

[74] "Biodiesel: Biodiesel Review," 2006. http://www.sipef. be/pdf/biodiesel_presentation.pdf

[75] L. C. Meher, D. V. Sagar and S. N. Naik, "Technical Aspects of Biodiesel Production by Transesterification-A Review," Renewable \& Sustainable Energy Re- views, Vol. 10, No. 3, 2006, pp. 248- 268.

[76] R. Sharma, Y. Chisti and U. C. Banerjee, "Production, Purification, Characterization, and Applications of Lipases," Biotechnology Advance, Vol. 19, No. 8, 2001, pp. 627- 662 .

[77] H. Fukuda, A. Kondo and H. Noda, "Biodiesel Fuel Production by Transesterification of Oils," Journal of Bioscience and Bioengineering, Vol. 92, No. 5, 2001, pp. 405- 416.

[78] S. Pedersen and M. W. Christensen, "Immobilized Biocatalysts," Applied biocatalysis. P. Adlercreutz, Harwood Academic Publishers, Amsterdam, 2000, pp. 213-228.

[79] A. Salis, E. Sanjust, V. Solinas and M. Monduzzi, "Commercial Lipase Immobilization on Accurel MP1004 Porous Polypropylene," Biocatalysis and Biotransformation, Vol. 23, No. 5, 2005, pp. 381-386.

[80] H. M. Chang, H. F. Liao, C. C. Lee and C. J. Shieh, "Optimized Synthesis of Lipase-Catalyzed Biodiesel by Novozym 435," Journal of Chemical Technology \& Biotechnology, Vol. 80, No. 3, 2005, pp. 307-312.

[81] D. De Oliveira, M. Di Luccio, C. Faccio, C. D. Rosa, J. P. Bender, N. Lipke, S. Menoncin, C. Amroginski and J. V. De Oliveira, "Optimization of Enzymatic Production of Biodiesel from Castor Oil in Organic Solvent Medium," Applied Biochemistry and Biotechnology, Vol. 115, No. 1-3, 2004, pp. 771-780.

[82] G. Kminek and J. L. Bada, "The Effect of Ionizing Radiation on the Preservation of Amino Acids on Mars. Earth Planet," Science Letters, Vol. 245, No. 1-2, 2006, pp. 1-5.

[83] L. D. Barron, "Chirality and Life," Space Science Reviews, Vol. 135, No. 1-4, 2008, pp. 187-201.

[84] L. D. Hutt, D. P. Glavin and R. A. Mathies, "Microfabricated Capillary Electrophoresis Amino Acid Chirality Analyzer for Extraterrestrial Exploration," Analytical Chemistry, Vol. 71, No. 18, 1999, pp. 4000-4006.

[85] "Exomars Mission Conference," 2005. http://www. aurora.rl.ac.uk/Report_of_Pasteur_9_Sept.pdf

[86] L. Cao and Schmidt, "Immobilized Enzymes: Science or Art?" Current Opinion in Chemical Biology, Vol. 9, No. 2, 2005, pp. 217-226.

[87] B. Chen, M. E. Miller and R. A. Gross, "Effects of Porous Polystyrene Resin Parameters on Candida Antarctica Lipase B Adsorption, Distribution, and Polyester Synthesis Activity," Langmuir, Vol. 23, No. 11, 2007a, pp. 6467-6474.

[88] M. I. Kim, J. Kim, J. Lee, H. Jia, H. Bin Na, J. K. Youn, J. H. Kwak, A. Dohnalkova, J. W. Grate and P. Wang, "Crosslinked Enzyme Aggregates in Hierarchically-Ordered Mesoporous Silica: A Simple and Effective Method for Enzyme Stabilization," Biotechnology and Bioengineering, Vol. 96, No. 2, 2007, pp. 210-218.

[89] M. C. Rosales-Hernandez, J. E. Mendieta-Wejebe, J. Correa-Basurto, J. I. Vazquez-Alcantara, E, Terres-Rojas and J. Trujillo-Ferrara, "Catalytic Activity of Acetylcholinesterase Immobilized on Mesoporous Molecular Sieves," International Journal of Biological Macromole- 
cules, Vol. 40, No. 5, 2007, pp. 444-448.

[90] A. M. Wang, C. Zhou, H. Wang, S. B. Shen, J. Y. Xue and P. K. Ouyang, "Covalent Assembly of Penicillin Acylase in Mesoporous Silica Based on Macromolecular Crowding Theory," Chinese Journal of Chemical Engineering, Vol. 15, No. 6, 2007, pp. 788-790.

[91] A. Wang, H. Wang, S. Zhu, C. Zhou, Z. Du and S. Shen, "An Efficient Immobilizing Technique of Penicillin Acylase with Combining Mesocellular Silica Foams Support and P-Benzoquinone Cross Linker," Bioprocess and Biosystems Engineering, Vol. 31, No. 5, 2008a, pp. 509-517.

[92] T. Boller, C. Meier and S. Menzler, "Eupergit Oxirane Acrylic Beads: How to Make Enzymes Fit for Biocatalysis," Organic Process Research Development, Vol. 6, 2002, pp. 509-519.

[93] A. S. M. Chong and X. S. Zhao, "Design of Large-Pore Mesoporous Materials for Immobilization of Penicillin G Acylase Biocatalyst," Catalysis Today, Vol. 93-95, 2004, pp. 293-299.

[94] C. H. Lei, Y. S. Shin, J. Liu and E. J. Ackerman, "Entrapping Enzyme in a Functionalized Nanoporous Support," Journal of American Chemical Society, Vol. 124, No. 38, 2002, pp. 11242-11243.

[95] A. M. Wang, M. Q. Liu, H. Wang, C. Zhou, Z. Q. Du, S. M. Zhu, S. B. Shen and P. K. Ouyang, "Improving Enzyme Immobilization in Mesocellular Siliceous Foams by Microwave Irradiation," Journal of Bioscience and Bioengineering, Vol. 106, No. 3, 2008b, pp. 286-291.

[96] M. S. Cheung and D. Thirumalai, "Nanopore-Protein Interactions Dramatically Alter Stability and Yield of the Native State in Restricted Spaces," Journal of Molecular Biology, Vol. 357, No. 2, 2006, pp. 632-643.

[97] R. Szamocki, A. Velichko, F. Mucklich, S. Reculusa, S. Ravaine, S. Neugebauer, W. Schuhmann, R. Hempelmann and A. Kuhn, "Improved Enzyme Immobilization for Enhanced Bioelectrocatalytic Activity of Porous Electrodes," Electrochemistry Communications, Vol. 9, No. 8, 2007, pp. 2121-2127.

[98] R. J. Chen, Y. G. Zhang, D. W. Wang and H. J. Dai, "Noncovalent Sidewall Functionalization of SingleWalled Carbon Nanotubes for Protein Immobilization," Journal of American Chemical Society, Vol. 123, No. 16, 2001, pp. 3838-3839.

[99] L. S. Wan, B. B. Ke and Z. K. Xu, "Electrospun Nanofibrous Membranes Filled with Carbon Nanotubes for Redox Enzyme Immobilization," Enzyme Microbial Technology, Vol. 42, No. 4, 2008, pp. 332-339.

[100] G. Bayramoglu, S. Kiralp, M. Yilmaz, L. Toppare and M. Y. Arica, "Covalent Immobilization of Chloroperoxidase onto Magnetic Beads: Catalytic Properties and Stability," Biochemical Engineering Journal, Vol. 38, No. 2, 2008, pp. 180-188.

[101] A. Dyal, K. Loos, M. Noto, S. W. Chang, C. Spagnoli, K. Shafi, A. Ulman, M. Cowman and R. A. Gross, "Activity of Candida Rugosa Lipase Immobilized on Gamma-Fe2o3 Magnetic Nanoparticles," Journal of American Chemical Society, Vol. 125, No. 7, 2003, pp.
1684-1685.

[102] X. Q. Liu, Y. P. Guan, R. Shen and H. Z. Liu, "Immobilization of Lipase onto Micron-Size Magnetic Beads," Journal of Chromatography B-Analytical Technologies in the Biomedical and Life Sciences, Vol. 822, No. 1-2, 2005, pp. 91-97.

[103] S. Sadasivan and G. B. Sukhorukov, "Fabrication of Hollow Multifunctional Spheres Containing MCM-41 Nanoparticles and Magnetite Nanoparticles Using Layer-by-Layer Method," Journal of Colloid and Interface Science, Vol. 304, No. 2, 2006, pp. 437-441.

[104] J. Kim, J. Lee, H. B. Na, B. C. Kim, J. K. Youn, J. H. Kwak, K. Moon, E. Lee, J. Park and A. Dohnalkova, “A Magnetically Separable, Highly Stable Enzyme System Based on Nanocomposites of Enzymes and Magnetic Nanoparticles Shipped in Hierarchically Ordered, Mesocellular, Mesoporous Silica," Small, Vol. 1, 2005, p. 1203.

[105] I. Hegedus and E. Nagy, "Improvement of Chymotrypsin Enzyme Stability as Single Enzyme Nanoparticles," Chemical Engineering Science, Vol. 64, No. 5, 2009, pp. 1053-1060.

[106] M. Yan, J. Ge, Z. Liu and P. K. Ouyang, "Encapsulation of Single Enzyme in Nanogel with Enhanced Biocatalytic Activity and Stability," Journal of American Chemical Society, Vol. 128, No. 34, 2006, pp. 11008-11009.

[107] J. Kim and J. W. Grate, "Single-Enzyme Nanoparticles Armored by a Nanometer-Scale Organic/Inorganic Network," Nano Letters, Vol. 3, No. 9, 2003, pp. 1219-1222.

[108] Y. Tanaka, Y. Tsuruda, M. Nishi, N. Kamiya and M. Goto, "Exploring Enzymatic Catalysis at a Solid Surface: A Case Study with Transglutaminase-Mediated Protein Immobilization," Organic Biomolecular Chemistry, Vol. 5, No. 11, 2007, pp. 1764-1770.

[109] L. S. Wong, J. Thirlway and J. Micklefield, "Direct Site-Selective Covalent Protein Immobilization Catalyzed by a Phosphopantetheinyl Trans Ferase," Journal of American Chemical Society, Vol. 130, No. 37, 2008, pp. 12456-12464.

[110] K. Buchholz, "Non Uniform Enzyme Distribution Inside Carriers," Biotechnology Letters, Vol. 1, No. 11, 1979, pp. 451-456.

[111] B. Chen, E. M. Miller, L. Miller, J. J. Maikner and R. A. Gross, "Effects of Macroporous Resin Size on Candida Antarctica Lipase B Adsorption, Fraction of Active Molecules, and Catalytic Activity For Polyester Synthesis," Langmuir, Vol. 23, No. 3, 2007b, pp. 1381-1387.

[112] L. M. Van Langen, M. H. A. Janssen, N. H. P. Oosthoek, S. R. M. Pereira, V. K. Svedas, F. van Rantwijk and R. A. Sheldon, "Active Site Titration as a Tool for the Evaluation of Immobilization Procedures of Penicillin Acylase," Biotechnology Bioengineering, Vol. 79, No. 2, 2002, pp. 224-228.

[113] A. M. Wang, C. Zhou, M. Q. Liu, Z. Q. Du, S. M. Zhu, S. B. Shen and P. K. Ouyang, "Enhancement of Microwave-Assisted Covalent Immobilization of Penicillin Acylase Using Macromolecular Crowding And Glycine 
[114] A. Naqvi and P. Nahar, "Photochemical Immobilization of Proteins on Microwave-Synthesized Photoreactive Polymers," Analytical Biochemistry, Vol. 327, No. 1, 2004, pp. 68-73.

[115] S. Kumar and P. Nahar, "Sunlight-Induced Covalent Immobilization of Proteins," Talanta, Vol. 71, No. 3, 2007, pp. 1438-1440.

[116] R. D. Rogers and K. R. Seddon, "Ionic Liquids-Solvents of the Future?" Science, Vol. 302, No. 5646, 2003, pp. 792-793.

[117] K. E. Gutowski, G. A. Broker, H. D. Willauer, J. G. Huddleston, R. P. Swatloski, J. D. Holbrey and R. D. Rogers, "Controlling the Aqueous Miscibility of Ionic Liquids:
Aqueous Biphasic Systems of Water-Miscible Ionic Liquids and Water-Structuring Salts for Recycle, Metathesis, and Separations," Journal of American Chemical Society, Vol. 125, No. 22, 2003, pp. 6632-6633.

[118] V. Rumbau, R. Marcilla, E. Ochoteco, J. A. Pomposo and D. Mecerreyes, "Ionic Liquid Immobilized Enzyme for Biocatalytic Synthesis of Conducting Polyaniline," Macromolecules, Vol. 39, No. 25, 2006, pp. 8547-8549.

[119] R. A. Sheldon, R. M. Lau, M. J. Sorgedrager, F. Van Rantwijk and K. R. Seddon, "Biocatalysis in Ionic Liquids," Green Chemistry, Vol. 4, 2002, pp. 147-151.

[120] F. Van Rantwijk, R. M. Lau and R. A. Sheldon, "Biocatalytic Transformations in Ionic Liquids," Trends Biotechnology, Vol. 21, No. 3, 2003, pp. 131-138. 